\title{
Integrating local pastoral knowledge, participatory mapping, and species distribution modeling for risk assessment of invasive rubber vine (Cryptostegia grandiflora) in Ethiopia's Afar region
}

\author{
$\underline{\text { Matthew W. Luizza }}^{1}$, Tewodros Wakie $^{1}, \underline{\text { Paul H. Evangelista }}^{1}$ and Catherine S. Jarnevich $^{2}$
}

\begin{abstract}
The threats posed by invasive plants span ecosystems and economies worldwide. Local knowledge of biological invasions has proven beneficial for invasive species research, but to date no work has integrated this knowledge with species distribution modeling for invasion risk assessments. In this study, we integrated pastoral knowledge with Maxent modeling to assess the suitable habitat and potential impacts of invasive Cryptostegia grandiflora Robx. Ex R.Br. (rubber vine) in Ethiopia's Afar region. We conducted focus groups with seven villages across the Amibara and Awash-Fentale districts. Pastoral knowledge revealed the growing threat of rubber vine, which to date has received limited attention in Ethiopia, and whose presence in Afar was previously unknown to our team. Rubber vine occurrence points were collected in the field with pastoralists and processed in Maxent with MODIS-derived vegetation indices, topographic data, and anthropogenic variables. We tested model fit using a jackknife procedure and validated the final model with an independent occurrence data set collected through participatory mapping activities with pastoralists. A Multivariate Environmental Similarity Surface analysis revealed areas with novel environmental conditions for future targeted surveys. Model performance was evaluated using area under the receiver-operating characteristic curve (AUC) and showed good fit across the jackknife models (average $\mathrm{AUC}=0.80$ ) and the final model (test AUC $=0.96$ ). Our results reveal the growing threat rubber vine poses to Afar, with suitable habitat extending downstream of its current known location in the middle Awash River basin. Local pastoral knowledge provided important context for its rapid expansion due to acute changes in seasonality and habitat alteration, in addition to threats posed to numerous endemic tree species that provide critical provisioning ecosystem services. This work demonstrates the utility of integrating local ecological knowledge with species distribution modeling for early detection and targeted surveying of recently established invasive species.
\end{abstract}

Key Words: Afar region; citizen science; Cryptostegia grandiflora; Ethiopia; invasive species; local ecological knowledge; Maxent; participatory mapping; pastoral livelihoods; risk assessment; rubber vine; species distribution modeling

\section{INTRODUCTION}

Invasive plants are one of the most serious threats to ecosystems and economies worldwide (IUCN 2000, Pimentel 2005, Vilà et al. 2010). These problematic non-native species are known to have negative impacts on biodiversity, ecosystem functioning, and an array of other natural processes and human activities (Vitousek 1990, Hejda et al. 2009). The increasing threat of invasive plants is fueled by a diverse set of fast- and slow-paced human disturbance drivers including climate change (Thuiller et al. 2007), habitat alteration and fragmentation (With 2004), intentional introductions (Mack and Erneberg 2002), and an increasingly globalized horticulture trade (Bradley et al. 2012). Vines (herbaceous and shrubby climbing plants) can prove especially problematic upon establishment in novel areas. This is because of their fast growth rates, which facilitate their ability to out-compete host vegetation by blocking access to light, ultimately reducing host survival and dramatically altering ecosystem structure. A number of vines are considered among the 100 worst global invasive alien species, including Hiptage (Hiptage benghalensis), kudzu (Pueraria montana var. lobata), and mile-a-minute-vine (Mikania micrantha; Lowe et al. 2000), yet to date few studies have explored the interconnected threats invasive vines pose for sensitive arid ecosystems and local livelihoods.

Early detection of invasive plants, facilitated through mapping efforts, is critical for rapid response and effective monitoring strategies (Kaplan et al. 2014). The utility of risk assessment procedures for addressing invasive plants has grown in recent years (Powell 2004, Lindgren 2012), including powerful applications of species distribution modeling techniques (Evangelista et al. 2008, Andrew and Ustin 2009, Stohlgren et al. 2010, Jarnevich et al. 2011). These models combine and quantify species occurrence location information with environmental data to develop relationships to predict a given species' distribution across a defined geographic space (Franklin 2010). Collaboration and data sharing with regard to invasive species have improved, as evidenced by a number of regional and global species occurrence data repositories, e.g., Global Biodiversity Information Facility, Global Invasive Species Information Network, Invasive Species Compendium, and National Institute of Invasive Species Science. However, these species often do not have easily accessible, and perhaps even any available, data until they become widespread problems at the national or global scales. Furthermore, field surveys can be time- and cost-intensive, thus limiting early detection efforts. Ecological knowledge of local communities can provide an important tool for early detection and understanding of invasion impacts. This is critical because such knowledge integration may afford the necessary edge to address invasive species that have not fully established or dispersed widely across the landscape. Despite an array of research noting the importance of local ecological knowledge for resource 
management and conservation planning (Ballard et al. 2008, Berkes and Berkes 2009, Gagnon and Berteaux 2009), and the growing call for broader inclusion of stakeholder perceptions in invasion research (García-Llorente et al. 2008, Kapler et al. 2012), consideration of local ecological knowledge within risk assessment studies, particularly species distribution modeling research, is lacking. Recent studies have begun exploring the interactions between invasive species and ecosystem services that resource-dependent communities rely on (Mwangi and Swallow 2008, Kull et al. 2011, Shackleton et al. 2011). Expanding such work is greatly needed because invaders can often have detrimental impacts on an array of services, posing major threats to local livelihoods (Pejchar and Mooney 2009, Urgenson et al. 2013).

Ethiopia's Afar region is facing the threat of multiple aggressive non-native plants including mesquite (Prosopis juliflora), whitetop weed (Parthenium hysterophorus L.), and the recently established rubber vine (Cryptostegia grandiflora Roxb. Ex R. Br.; Yohannes et al. 2011). Rubber vine is a woody perennial vine of the Asclepiadaceae family that is native to Madagascar. Although not currently listed as an invasive alien species in Ethiopia (Invasive Species Compendium 2014), it potentially poses a major threat to biodiversity and local pastoral livelihoods in Afar (Fig. 1). It is an adaptive species that is stress tolerant and highly competitive in arid environments with limited water. The vine is known to rapidly capitalize on small amounts of moisture for germination, produce thousands of pappus seeds that can spread by wind or water, and develop a deep taproot (Grice 1996, Brown et al. 1998). Rubber vine is highly invasive in other semiarid and arid landscapes where it has been introduced including Australia, Mexico, and the United States (Invasive Species Compendium 2014). In Australia, where the species has been established since the late 19th century, it is noted to drastically alter ecosystems and fire regimes, promoting a shift from frequent grass-dominant surface fires to infrequent but more intense crown fires (Grice 1997, Radford et al. 2008). It can form dense mono-specific stands, especially in riparian areas (Kriticos et al. 2003) and tolerate a range of soil conditions including sodic and saline. In Mexico, rubber vine is known to outcompete native vegetation, altering important habitat for an array of vertebrate and invertebrate species (Rodríguez-Estrella et al. 2010). Although the origin of rubber vine introduction to Ethiopia is uncertain, it was introduced intentionally in other locations as an ornamental plant (Kriticos et al. 2003, Rodríguez-Estrella et al. 2010) and grown during World War II as a natural rubber source (Augustus et al. 2000). Based on our discussions with them, pastoralists in Afar tend to agree that the vine first appeared in the middle Awash River basin within the past 20 years, concurrent with increased frequency and magnitude of flooding events. To our knowledge no research exists that assesses the suitable habitat of rubber vine and its impacts on pastoral communities in Ethiopia, and few studies have explored the benefits of cataloguing pastoral knowledge in Afar for conservation planning and management (see Giday and Teklehaymanot 2013 and Tsegaye et al. 2010 for notable exceptions). Our goals for this study included the following: (1) integrate local pastoral knowledge and participatory mapping with species distribution modeling to map the suitable habitat of rubber vine in the Afar region, (2) catalogue pastoral knowledge and perceptions of rubber vine negative impacts on local livelihoods and the landscape, and (3) assess the utility of integrating local pastoral knowledge with species distribution modeling for invasion risk assessment studies.

Fig. 1. Local ecological knowledge integration process with Afar pastoralists and rubber vine negative impacts. (a) Focus group with pastoralists, which revealed the greatest threats to local livelihoods, changes witnessed on the landscape, and growing concerns regarding rubber vine. (b) Afar pastoralists identifying invasive plants with the assistance of Landsat 8 satellite imagery during participatory mapping activities. (c) Rubber vine growing in shrub form in a disturbed area adjacent to a cotton field. (d) Participatory field data collection with pastoralists, including collection of rubber vine occurrence points for the risk assessment model. Rubber vine growing in shrub form (foreground). Other vines growing in tree canopies in the background, with the Awash River behind the vehicle. (e) Dried rubber vine seedpod revealing thousands of pappus seeds, which are easily distributed by wind and water. (f) Immature seed pod dripping milky latex sap. The sap is poisonous if ingested by livestock and is a skin irritant. All images courtesy of M. Luizza.
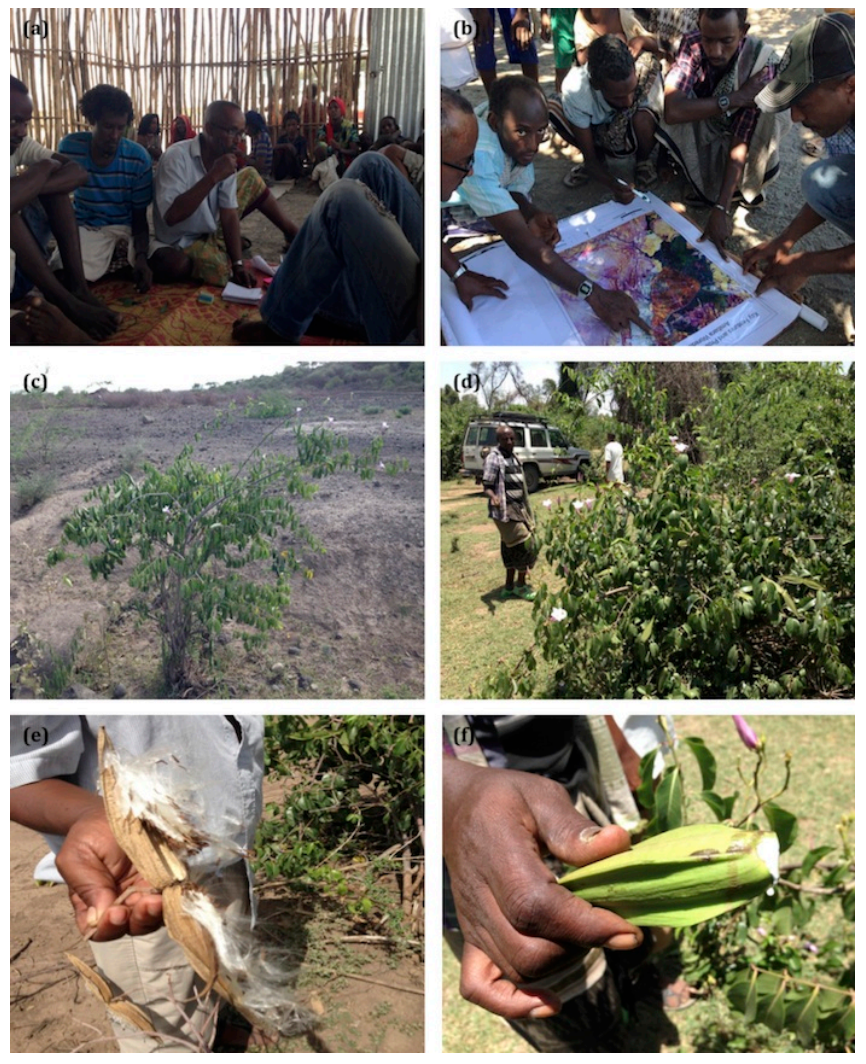

\section{MATERIALS AND METHODS}

\section{Study site}

The Afar region (Fig. 2) is located in northeastern Ethiopia (between $8^{\circ} 51^{\prime}$ and $14^{\circ} 34^{\prime} \mathrm{N}$ and between $39^{\circ} 47^{\prime}$ and $42^{\circ} 24^{\prime} \mathrm{E}$ ), and is one of the country's nine administrative states. The Afar covers an area of approximately $95,266 \mathrm{~km}^{2}$ and is split into five 
administrative zones that are further subdivided into 29 districts (woredas) and 355 kebeles, the smallest administrative unit in Ethiopia. The region is topographically diverse, with elevations ranging from $125 \mathrm{~m}$ below sea level to $2,870 \mathrm{~m}$ above sea level (Wakie et al. 2014), and is one of the hottest habitable places on earth, with temperatures surpassing $50^{\circ} \mathrm{C}$ and bimodal rainfall that is under $200 \mathrm{~mm}$ annually across large extents of the landscape (Davies and Bennett 2007). It holds a number of unique flora and fauna including endangered species such as the Abyssinian wild ass (Equus africanus asinus) and Grevy's zebra (Equus grevyi; Kebede et al. 2012, 2014). Vegetation here is made up of grasses, forbs, shrubs, and woody plants, well adapted to arid and semiarid environments including Acacia mellifera, A. nilotica, A. senegal, A. tortillis, Cadaba rotundfolia, Chrysopogon, Cymbopogon, Cynodon, and Dactyloctenium species, Dombera glabra, Salvadora persica, and Tamarix nilotica (Tikssa et al. 2010, Bahru et al. 2012, Wakie et al. 2014). Afar is home to approximately 1.5 million people of which the majority (nearly $80 \%$ ) are pastoralist (Sonneveld et al. 2009), meaning they derive more than $50 \%$ of their income from livestock and livestock products (Rota and Sperandini 2009). Afar is also the dominant ethnic group (approximately 90\%) and the main language spoken (Getachew 2001).

Fig. 2. Left: Afar region divided by its five administrative zones Upper Right: Afar region in relation to Ethiopia. Lower Right: Close up of the two districts (woredas) where we collected focus group and field data.

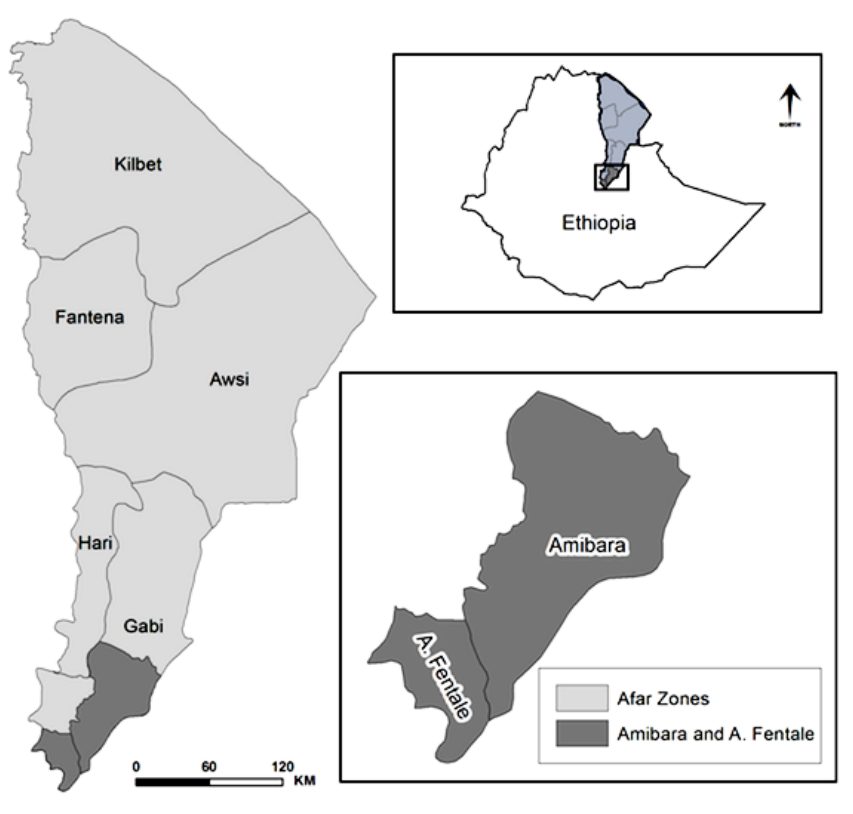

Local ecological knowledge data

This study was preapproved by the Social, Behavioral, and Education Research Institutional Review Board at Colorado State University (Protocol \# 14-5049H). We collected field data, including rubber vine occurrence points and local pastoral knowledge in April and May 2014. We catalogued pastoral knowledge through semistructured focus groups. This flexible approach allowed for the inclusion of different perspectives simultaneously (Morgan 1997) and provided an informal setting where unanticipated information could emerge (Huntington 1998). This proved fruitful because a communal setting facilitated the participation of some women, where otherwise they may not have been included because of a combination of cultural taboos and extended household duties. Focus groups lasted approximately three hours and were conducted in the local Afar dialect and the national language Amharic with the assistance of a local translator/research assistant. Focus group sessions began with a formal introduction, explaining the project objectives before receiving verbal consent by each participant.

Thirty-nine men and seven women participated in the focus groups across seven villages located within the Amibara and Awash-Fentale districts. Focus groups ranged in size from 5 to 10 people. Participants' ages ranged from 18 to 50 years, with over half between 26 and 40 . The average household size was 9 people. The majority (nearly 70\%) self-identified as pastoralists, predominately raising cattle, goats, and sheep, in addition to some camels, while the remaining individuals self-identified as agropastoralists, raising similar types of livestock, in addition to cultivating some crops including cotton and onions. In the interest of concision and the fact that pastoral activities still contribute to the majority of the self-identified agro-pastoralists' income, we subsequently refer to both groups collectively as pastoralists. Before conducting focus groups, we requested permission from the chairman of each village, allowing for greater ease in locating and recruiting participants spread out across a large geographic area. We used a convenience sampling approach (Patton 2002) to recruit participants who were present in the village at the time of our data collection. Although having some potential for sampling bias, we deemed this approach appropriate and purposive for cataloging the observations and perceptions of pastoralists with extensive knowledge of their local landscape because all participants were born in their respective village and spanned a number of primary and secondary occupations, including livestock husbandry, farming, local government, teaching, local leadership, i.e., village chairman, and religious leadership.

Focus group topics covered three broad areas: (1) Landscape-scale changes, which included questions such as, "Are there changes to nature which you have observed in your community during your lifetime, for example changes in plants, water, soils, or wildlife?" (2) Seasonality, which included questions such as, "When do the rains come?" (3) Plants and animals, which included questions such as, "Are there plants that you consider bad?" (see Appendix 1 for full list of interview questions). These questions were posed to determine the most pressing threats to pastoral livelihoods and further understand specific issues related to non-native invasive plants, while allowing the respondents the freedom to control the direction of the discussion.

\section{Model training data}

Focus groups revealed the growing presence of rubber vine, whose existence in the Afar region was previously unknown to our research team, and thus became the target of subsequent field data collection and analyses. Our original purpose was to understand the impacts of invasive Prosopis juliflora on pastoral livelihoods and local adaptations to its presence. We recorded 24 rubber vine observations with geographic coordinates (occurrence points) with a handheld GPS unit. Focus group 
participants identified and guided our team to locations of rubber vine in the field. We reduced the initial 24 points to 18 through the FieldDataAggregateAndWeight module located within the USGS Software for Assisted Habitat Modeling (SAHM v1.2; Morisette et al. 2013). This preprocessing module removed overlapping points within the same $250 \mathrm{~m}$ cell. With such a limited data set, we used Maximum entropy (Maxent) modeling, which is known to work well with small sample sizes (Pearson et al. 2007, Wisz et al. 2008). We used SAHM's BackgroundSurfaceGenerator module to produce a surface with values between 0 and 100 using the 18 rubber vine locations as inputs, and created a Kernel Density Estimator (KDE) surface. We produced 10,000 background points within SAHM using this surface to weight their placement. This method is useful to mimic bias in presence locations due to sampling bias and continued spread of an invasive species (Elith et al. 2010). Additionally, this process helped to smooth out the contribution of each occurrence point over the localized sampling extent (Hernandez et al. 2006).

\section{Model validation data}

Following the focus group interviews, we conducted participatory mapping activities with the same pastoralists to create an independent validation data set for the model, using mosaicked, pan-sharpened (to $15 \mathrm{~m}$ resolution) Landsat 8 satellite images that included the two districts within our study region (see Appendix 2 for full list of scenes). We overlaid the images with clear acetate paper and participants used permanent markers to denote the locations of invasive plants and important water resources across the landscape. We superimposed villages and towns on the highresolution imagery and clearly labeled them. These major landmarks helped participants to rapidly familiarize themselves with the presented maps.

\section{Environmental variables}

We chose environmental variables based on the most important ecological and anthropogenic characteristics that might determine the distribution of rubber vine across the study area. We acquired this knowledge of hydrologic and biophysical features and human-induced disturbance drivers from a number of sources, including local pastoral knowledge, background literature reviews (Grice 1996, Brown et al. 1998, Kriticos et al. 2003), and field observations. We derived the Normalized Difference Vegetation Index (NDVI; Tucker 1979) from the National Aeronautics and Space Administration (NASA) Moderate Resolution Imaging Spectroradiometer (MODIS) satellite, to capture the reflectance of healthy green vegetation including rubber vine and native acacia trees that it often grows on. We acquired NDVI from the Land Processes Distributed Active Archive Center, with all preprocessing steps conducted with the MODIS Reprojection Tool. We included August and November NDVI from 2012, to capture the two main rainy seasons of the Afar region: kerma, which peaks in August, and detrob, which peaks in November. Although the vine can bloom all year with sufficient moisture and grow on its own in a shrub form, it tends to thrive in semishaded riparian areas, growing into the canopy of trees. An important caveat is that the spectral signature captured by NDVI may include invasive $P$. juliflora, with which rubber vine has been observed growing in concert (M. W. Luizza, personal observation), and therefore might pose issues for vegetation spectral signature confusion.
We also included three topographic variables: elevation, slope, and compound topographic index (CTI), all of which we obtained from the digital elevation model (DEM) acquired from the Shuttle Radar Topography Mission. We derived slope and CTI from the DEM and resampled them in ArcGIS v10.0 (ESRI 2011) to 250 $\mathrm{m}$ spatial resolution using the nearest neighborhood algorithm to match the resolution of the MODIS-derived NDVI predictors. CTI is a calculation that uses slope and flow accumulation to identify drainage depressions and provides a representation of soil wetness across a given landscape (Evans et al. 2014).

We considered three anthropogenic variables that may provide pathways of rubber vine introduction, thus acting as a proxy for propagule pressure and disturbance (Jarnevich et al. 2014): distance to roads, derived from a current roads geospatial layer for the Afar region, and distance to water, derived from a current rivers and streams geospatial layer for Afar. We acquired both layers from the Afar Pastoral Agriculture and Rural Development Bureau. We cross-referenced these data for accuracy with additional geospatial data sets and sources. This included overlaying the roads layer on the ESRI world 2D base map in ArcGIS, and cross-referencing the rivers and streams layers with an independent rivers and streams layer created with the ArcHydro 2.0 tool set. Both visual validation procedures produced strong agreement between the different data sources. Additionally, we created a distance to settlements layer using 23 GPS locations of towns and villages collected within the study area. We created distance layers for all three using the Euclidean distance calculation in ArcGIS 10.0 with a spatial resolution of $250 \mathrm{~m}$. This calculation measures the straight line distance of the centroid of each cell in a given raster to the centroid of a given source cell (Hirzel and Arlettaz 2003), which in the case of our study included all three of our anthropogenic variables.

We examined all pairwise combinations of predictors using a correlation matrix generated by SAHM's CovariateCorrelationAndSelection module (see Appendix 3 for full matrix). To identify and avoid using redundant variables, we removed one of any pair with a Spearman, Pearson, or Kendal correlation of $|\mathrm{r}|>0.70$, following the recommendation of Dormann et al. (2013). For this study August and November NDVI were the only highly correlated variables. August is part of the longer, primary rainy season kerma, and was therefore deemed to be a more robust predictor for the model, resulting in the removal of November NDVI from use in the final model runs.

\section{Rubber vine modeling}

We conducted all preprocessing and modeling procedures within SAHM, which is freely available and designed to expedite habitat suitability modeling procedures (Morisette et al. 2013). Within SAHM we used the Maxent statistical software package version 3.3.3k to train the model (Phillips et al. 2006). This modeling approach is a general-purpose machine learning method that models species distributions from presence-only species occurrence records and has high accuracy in predicting plant distributions (Evangelista et al. 2009, Elith et al. 2011). The Maxent modeling output creates a surface with a continuous habitat suitability gradient with values ranging from 0 (least suitable or dissimilar) to 1 (most suitable or most similar to cells with occurrence points) and provides a calculation of the percent contribution of the different environmental variables used in the model. 
We used a jackknife validation approach to test overall model fitness because of the limited number of rubber vine occurrence points. Pearson et al. (2007) provide strong support for Maxent's ability to produce robust model results with small species occurrence data sets (as small as 5). With such limited data sets, models are greatly influenced by exactly which observations are included. Using their novel jackknife procedure, we generated 18 models, equaling the total number of occurrence points, to test overall model fitness. Each occurrence was removed from the data set and the model was built on the remaining points. The predictive performance was then assessed based on each model's ability to predict the single occurrence point excluded from the training data set. A final model trained with all 18 occurrence points was run after determining model fitness through this process, and produced a continuous probability raster of predicted suitable rubber vine habitat across the Afar region.

\section{Independent modeling validation and novel environment identification}

Independent validation data to evaluate the final model came from participatory mapping with the same focus group participants. Three villages noted rubber vine locations on the satellite image for the Amibara district. From this, we generated 52 rubber vine occurrence points. This set was later reduced to 50 validation points within SAHM's FieldDataAggregateAndWeight module. We digitized rubber vine occurrences from the participatory mapping activities in ArcGIS 10.0. We ran all participatory mapping test data through SAHM's ApplyModel module to validate the final rubber vine habitat suitability model. Additionally, we switched model occurrence data sets to explore the utility of training and testing the model with more stratified participatory field sampling data compared to the more clustered participatory mapping occurrence points. Model results were assessed based on the AUC. The area under the receiver-operating characteristic curve is a threshold-independent metric, with values ranging from 0 to 1 that measures the ability of a model to discriminate a true occurrence point from an absence or background point. An AUC value of less than 0.5 shows that model predictions were worse than random, a value of 0.5 no better than random, and a value of 1.0 indicating perfect discrimination (Peterson et al. 2011, Khanum et al. 2013).

One model output was a Multivariate Environmental Similarity Surface (MESS) map, which provides a measurement of the congruence of the value of any predictor at any given point to the values at the locations used to train the model (Elith et al. 2011). This surface provides a visualization of where model predictions are extrapolating beyond the environmental conditions used to train the model (specifically for each point, the extent to which the most dissimilar variable is outside the training range), and thus denotes locations where model predictions are less certain because of novel conditions. We overlaid results from this study on the MESS map to provide additional model assessment and prioritize areas for future targeted surveying and monitoring efforts with pastoralists.

\section{RESULTS}

Negative impacts of rubber vine on pastoral livelihoods

High levels of agreement were found between men and women relating to knowledge and perceptions of rubber dispersal mechanisms, negative impacts, and changes occurring across the landscape (Table 1). In many instances, observations shared by one gender were corroborated and expanded upon by the other. Across all seven villages, focus group participants described combined pressures of extensive drought, reduced water flow from the Awash River because of large-scale government farms, and the influx of invasive species. A number of pastoralists clearly noted the connections between all three issues, with drought facilitating the establishment of invasive plants, and large-scale agriculture development disturbing the land and providing novel habitat for these invaders through extensive irrigation ditches. "The pastoralist way of life is changing," one respondent declared. "When native species were plentiful," the respondent added, "we used to have cold air and plenty of water. Now it is reversed, invasive plants, hot air, and little water."

Table 1. Pastoralist observations of rubber vine (Cryptostegia grandiflora) dispersal mechanisms, threats, and negative impacts across the seven village focus groups with illustrative quotes. Frequency denotes the number of villages that made the same observation. Local plant names are in italics, including halemero (rubber vine), weyane ( $P$. juliflora), and wola howla ( $P$. hysterophorous).

Observation and Frequency Illustrative quote(s)

$(\max \mathrm{n}=7)$

Rubber vine in concert with "The grass and range is degraded... other invasive plants degrades native plant species have disappeared the landscape (7) and now we have weyane, halemero, and wola howla."

Rubber vine provides habitat for predators resulting in increased attacks on livestock (5)

"It [rubber vine] has vines that can bind and trap our livestock and they are attacked by wild animals like hyena... Lion are also moving into the weyane and halemero forests"

Rubber vine rapidly spreads by water (often fueled by industrial agriculture) and wind (5)

"Halemero is found near the Awash River on both sides. It spreads by water."

"The sugar cane industry has caused many changes to vegetation. Indigenous plants have declined and new invasive species are increasing, including wola howla, halemero, and weyane."

"Halemero has many small seeds within the large pods found on mature plants. The pods dry, burst open and release all of the small seeds which spread by the wind."

Rubber vine kills native vegetation (4)

Rubber vine is poisonous to livestock (3)
"If it [rubber vine] grows in an area, no grass will grow near it. It grows like a vine and chokes other plants, including native trees."

"Halemero is poisonous and if cattle accidentally eat the leaves, they die." 
Acute changes to all four major rainy seasons were additionally noted, with each experiencing noticeable reductions in the volume and predictability of rainfall. These factors are believed by many pastoralists to be helping spread invasive plants. Kerma, the primary rainy season historically spanning four months from June to September, is now limited to the month of August. Detrob, the secondary rainy season, which in the recent past spanned October and November, now only occurs over a maximum span of five days. Dedaa, which historically spanned January and February, and segum, which occurred in April, have disappeared entirely. One respondent emphatically relayed that dedaa and detrob had already passed this year with no rain. This observation was met with the agreement of other pastoralists, with the same person somberly adding, "What is left are only the names of the seasons."

Although pastoralists described two other invasive plants as problematic, including the regionally prolific weyane (Prosopis juliflora) and the nationally invasive wola howla (Parthenium hysterophorus), all participants noted halemero (rubber vine) to be the newest invasive plant to Afar and of growing concern. A majority of the villages (six of the seven) relayed that rubber vine has noticeably increased in cover in recent years. Participants noted that rubber vine grows in close proximity to the Awash River on both sides and first appeared in Afar in the upper and middle Awash River approximately 20 years ago (during the communist Derg Regime). A majority of respondents agreed that the vine is seed-propagated primarily through water, although it can also disperse its seeds by wind. Major flood events including those in 1998 were noted to assist in the establishment of the vine, and the increased frequency and magnitude of these events in recent years has further exacerbated the situation. Respondents relayed that when the Awash River would historically flood, native grasses would sprout. In recent years when flooding occurs, grass does not grow, only rubber vine and $P$. hysterophorus. A number of respondents argued that this recent phenomenon is in part because of the massive influx of large-scale government-owned sugar cane farms in the river valley. These monoculture industrial agriculture operations are water-intensive, requiring extensive irrigation ditch systems that follow the adjacent dirt roads. Many pastoralists believe these ditches are creating new habitat and seed dispersal systems for rubber vine, which is increasingly present in these recently disturbed areas (M. W. Luizza and T. Wakie, personal observations). Such observations corroborate existing work on the importance of human dispersal for facilitating the spread of invasive species (Hulme 2006, 2009).

All respondents quickly expressed that rubber vine has a number of negative impacts. If livestock, especially cattle, unintentionally eat the leaves while browsing other species, they become sick and can die suddenly. Existing research on rubber vine confirms the vine to be poisonous, containing glycosides that have toxic effects on the cardiac system if ingested (Cook et al. 1990, Mekonnen 1994). Some people use the plant's milky latex sap as a livestock insecticide, applying it to insects that are attached to cattle. However, this is not widely practiced because, as a number of participants explained, the sap is also a skin irritant and will burn a person if any touches exposed skin. No other beneficial uses of rubber vine were noted, although Afar and Oromo people in and around Awash National Park (located in the upper Awash River basin to the south of our study area), have confirmed using rubber vine bark, branches, and stems for house construction and tying material (Bahru et al. 2012). Additionally, like $P$. juliflora, rubber vine produces dense vegetation cover that poses a dual threat of restricting the mobility of livestock and providing cover for predators. Respondents noted that the vine can quickly bind and trap livestock, making them easy targets for hyena predation. The frequency of such attacks were noted to be on the rise, as the dense cover created by rubber vine and $P$. juliflora together has created shelter for a number of problematic wild animals such as lions, hyenas, leopards, and snakes. A few pastoralists went on to state that snakes and leopards particularly take advantage of rubber vine habitat corridors.

Rubber vine kills native trees by growing up into their canopy, blocking their access to the sun and "choking them," in addition to inhibiting the establishment of grasses when growing in shrubform. As one respondent exclaimed, "Where halemero grows, nothing else will!" The vine was said to have acute negative impacts on a number of native trees around the Awash River that are important to pastoral livelihoods. We catalogued eight endemic tree species that pastoralists identified as being threatened by rubber vine (alone or in concert with $P$. juliflora) and act as critical sources of firewood (see Appendix 4 for a full list of local trees and their uses). The three most important species, locally called keselto (Acacia nilotica), adado (Acacia senegal), and kilaito (Combretum aculeatum), collectively provide nine distinct provisioning ecosystem services including charcoal, construction, cosmetic, firewood, food, livestock fodder and forage, wildlife forage, medicinal, and shade services. Respondents emphasized that the most detrimental rubber vine impacts are seen with their most important firewood source $A$. nilotica, which is present along the Awash River. One respondent noted that no A. nilotica regeneration is occurring. "All we see are the remaining mature native trees; no new seedlings." Moreover, other respondents stated that combined impacts of rubber vine and $P$. juliflora have reduced important supplemental food sources. Pastoralists relayed that in the past there were an array of wild edible fruits that have recently disappeared from the landscape and been replaced with rubber vine and $P$. juliflora. One respondent added, "It even used to smell better with all the different flowering, fruitbearing plants. It is different now. Most of these edible fruits have disappeared." The fruit-bearing mederto (Cordia spp.) was stated to have been most noticeably affected, with a drastic decline in cover and extent.

\section{Rubber vine modeling}

Local pastoral knowledge greatly facilitated modeling the suitable habitat of rubber vine across the Afar region. Our preliminary jackknife validation approach revealed overall good model fit, with the average AUC value across the cross-validation subsets at 0.80 . Across all 18 cross-validation subsets, distance to water, August NDVI, and distance to roads were consistently in the top three predictors (see Appendix 5 for a full list of jackknife model performance and variable contribution). The final training model, run with all 18 rubber vine occurrence points, produced an AUC value of 0.91 and high classification accuracy (81.9\%). The final test model, validated with the 50 participatory mapping points, had strong discrimination with an AUC of 0.96 and high classification accuracy (92.9\%; see Table 2 for a full list of model evaluation measurements). For both model training and testing, the most influential predictors were distance to water, distance to roads, and August NDVI (Fig. 3). Upon switching the model 
occurrence data sets, i.e., training the model with the 50 participatory mapping points and testing with the 18 field collected points), model AUC values and correct classification percentages remained high, but model predictions were restricted to areas with existing rubber vine occurrence points. Moreover, model predictor importance shifted to topographic and different anthropogenic variables, and sensitivity, i.e., true positive rate, drastically decreased for the validation model.

Table 2. Maxent statistical accuracy measurements with the final model produced using field collected training data and participatory mapping (PGIS) test data, and switched data sets using participatory mapping training data and field collected test data.

\begin{tabular}{lcccc}
\hline \hline Data Set & AUC & $\begin{array}{c}\% \\
\text { Correctly } \\
\text { Classified }\end{array}$ & Sensitivity & Specificity \\
\hline Field Collected Training & 0.91 & 81.9 & 0.82 & 0.82 \\
Data & 0.96 & 92.9 & 0.92 & 0.93 \\
PGIS Test Data & 0.99 & 93.9 & 0.94 & 0.94 \\
PGIS Training Data & 0.99 & 99.4 & 0.35 & 1.00 \\
\hline Field Collected Test Data &
\end{tabular}

AUC $=$ area under the receiver-operating characteristic curve

Fig. 3. Relative contribution of each environmental predictor variable for the different training data. Higher percentage values indicate stronger influence on model response.

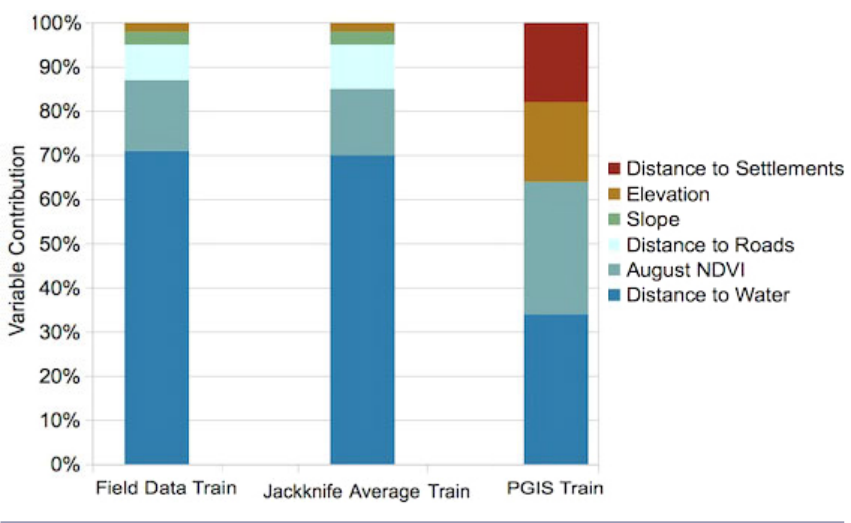

The final distribution map shows the growing threat rubber vine poses for the Afar region (Fig. 4). Overlaying the MESS map revealed $88 \%$ of the landscape to contain novel environmental characteristics outside of the range covered by the occurrence and background locations used to train the model (Fig. 4; Elith et al. 2010).

\section{DISCUSSION}

\section{Importance of local ecological knowledge}

The benefits of integrating local ecological knowledge with Western science are widely espoused. Examples demonstrate how this process can inform adaptive ecosystem management (Fernández-Giménez and Estaque 2012), facilitate effective comanagement between resource users and land managers
(Armitage et al. 2011), and afford a more holistic understanding about a given system (Gagnon and Berteaux 2009). Despite this, traditionally marginalized stakeholders, including women and indigenous peoples, may still be under-represented in these processes (Pfeiffer and Butz 2005, Ballard et al. 2008, Luizza et al. 2013), and great potential exists for knowledge co-option based on underlying power imbalances (Nadasdy 1999). Integrative risk mapping approaches, like those found in this study, can assist in reframing how invasion management and conservation planning is conducted to more actively address local community concerns. Going into the focus group interviews, our research team was well aware of the vulnerability of pastoralists and the Afar landscape to $P$. juliflora and $P$. hysterophorous. These semistructured interviews revealed the new and growing threat of rubber vine, which is currently not listed as an alien invasive species in Ethiopia, and receiving limited attention by local and regional government agencies and nonprofit organizations working in the area. Participatory data collection and mapping with pastoralists revealed the detailed and highly accurate knowledge of local community members regarding rubber vine. Model training and test data sets were independent, but collected from the same pastoralists. All 24 locations noted to have rubber vine by pastoralists across the seven village study sites were verified as having rubber vine presence by our research team. Additionally, much agreement existed between the three villages that identified rubber vine occurrences during the participatory mapping activities, although none of the villages viewed the maps created at the other sites. This provides another level of evidence of the utility of local ecological knowledge.

Local knowledge can act as an important early warning system to understand a given species' current distribution, biology, and impacts, and potentially provide a needed edge to more effectively mitigate and manage invasive species. This deep understanding of a local landscape can provide important long-term observations of ecosystem changes and the identification of nonnative species that may otherwise go unnoticed. Early detection of invasive plants is critical, and often the best response time is during the early stages of establishment when the least is known about the species-environment interactions and overall invasion potential (Kriticos et al. 2003). Model outputs were consistent with ecological knowledge of the species gained from pastoralists, field observations, and existing rubber vine studies, revealing high habitat suitability across much of the interconnected riparian areas of the Awash River basin. Additionally, the research process was enhanced by local knowledge helping to define the most useful model predictor variables and providing a better understanding of rubber vine negative impacts in a region where little is documented about its potential effects on the landscape and local livelihoods.

\section{Early detection of invasive plants}

Early detection and understanding of invasion impacts is critical for applied management efforts. This is made especially clear when viewing well-established invasive plants in the region such as $P$. juliflora, which will likely never be fully eradicated. Similar to the current view of many in Ethiopia with regard to rubber vine, $P$. juliflora was treated with much ambivalence during its early stages of establishment, even upon showing invasive characteristics (Dubale 2006, ESAP 2007). Prosopis juliflora is now considered the worst invasive species in Afar and one of the most harmful 
Fig. 4. Rubber vine (C. grandiflora) habitat suitability across the Afar region of Ethiopia. Areas in red denote predictions of high habitat suitability. Diagonal lines on the Multivariate Environmental Similarity Surface map inset signify locations with novel environmental characteristics.
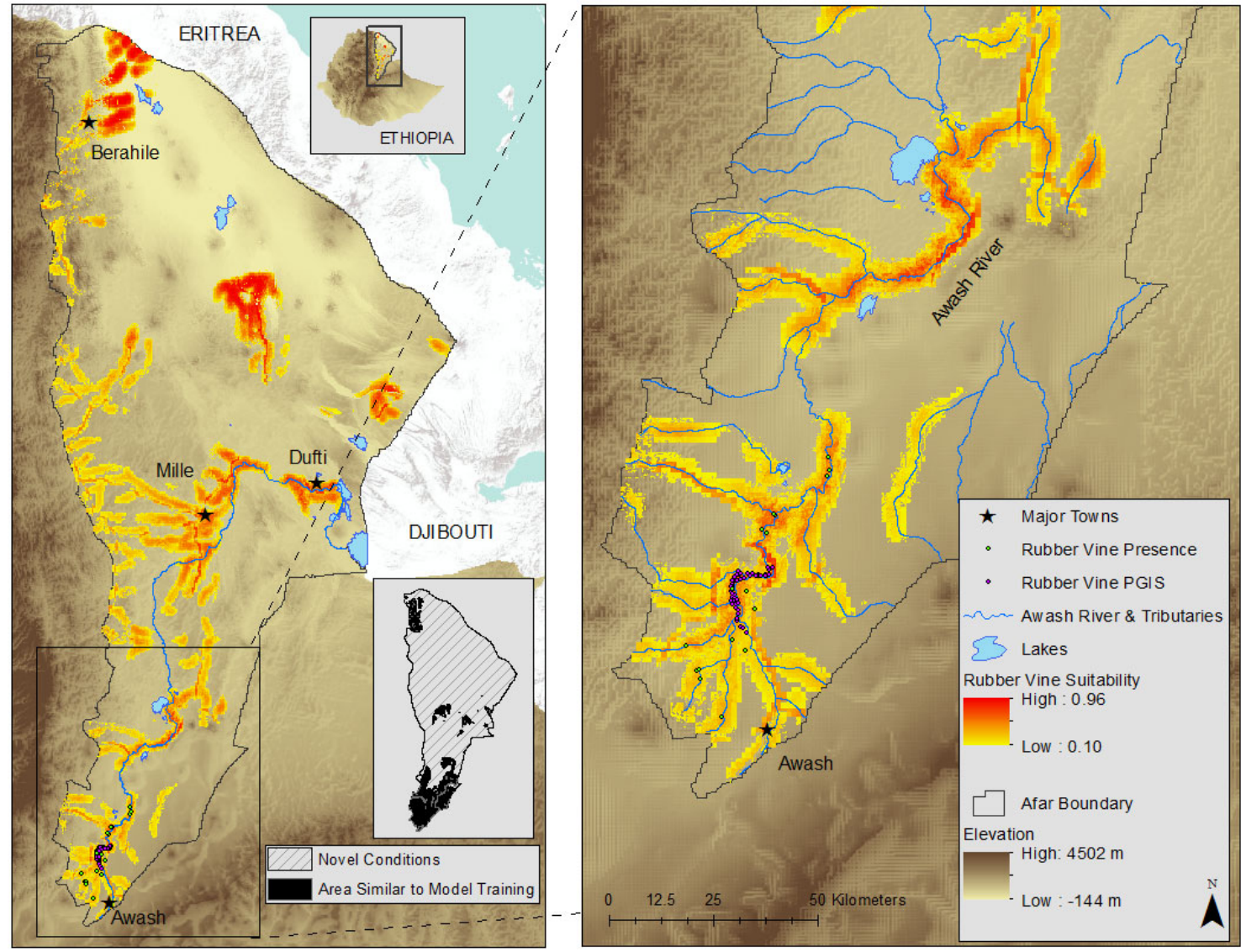

invasive plants in Ethiopia, having numerous direct and indirect economic, ecological, and local livelihood impacts (Getachew et al. 2012, Ayanu et al. 2015).

Viewing the effects of rubber vine in Australia, where it has long been established, relays the dire nature of quickly addressing this problematic species. Rubber vine has been described as the single biggest threat to natural ecosystems in tropical Australia (McFadyen and Harvey 1990). Although the vine is not a weed of agricultural crops, it smothers and out-competes both wild and pasture grasses in Australia, in addition to invading and disrupting forest systems (Tomley 1995). This has resulted in direct loss of pasture, with some infestations reducing the carrying capacity of livestock by up to $100 \%$, coupled with riparian area invasions limiting livestock access to water. From this, management costs have been estimated at US\$15 million per year to the northern Queensland beef industry alone (National Weeds Strategy Executive Committee 2001). Rubber vine could prove disastrous for Afar pastoralists who are heavily reliant on livestock. Pastoral livelihoods here have adapted to cope with uncertainty and the vulnerabilities associated with a harsh rangeland environment, but drought, collapse of livestock markets, and disease are preeminent shocks to which they are especially at risk (Davies and Bennett 2007). Moreover, impacts could easily move beyond the local level, as seen with $P$. juliflora in Ethiopia and rubber vine in Australia, potentially reaching the regional and national level because livestock are a major export commodity for Ethiopia (Catley et al. 2013). Pastoralists here depend on key riparian zones that provide important dry season and drought resources for herds, yet major drivers transforming riverine ecosystems threaten these assets, including dam construction, invasive species, and irrigated plantation farming (Behnke and Kerven 2013, Oba 2013). Such disturbances to the Awash River are especially prevalent and long-standing because the basin, which has merely $5 \%$ of Ethiopia's land area suitable for irrigation, has over one-third of its suitable land already irrigated, amounting to $50 \%$ of all land under irrigation in the entire country (Awulachew et al. 2007). Riparian areas are strongly influenced by the effects of human land use (Allan 2004) and invasive species have been shown to capitalize on these often interacting disturbances (Bradley and Mustard 2006, Crowl et al. 2008). The competing land uses present in the Awash River basin may further amplify the cumulative negative effects of rubber vine at the local and landscape scales. 


\section{Study challenges and caveats}

Challenges still exist for addressing rubber vine in the Afar region. Understanding the species' true ecological niche is difficult and the inclusion of additional environmental variables may be warranted in future modeling attempts. Rubber vine's native range is Madagascar, and this landscape poses certain challenges for fully understanding the vine's true habitat niche. For instance, the fact that Madagascar is an island quickly limits the species' dispersal capabilities. A few studies have explored rubber vine in its native range, finding its habitat to be characterized as dry tropical with highly pronounced summer rainfall (McFadyen and Harvey 1990), but Madagascar's limited climatic variation and competition between $C$. grandiflora and its genetically similar subspecies $C$. madagascariensis may belie the truly suitable climatic gradient that rubber vine can actually inhabit (Kriticos et al. 2003). This point is corroborated with observational evidence in the Afar region where rubber vine is found growing in very different habitat conditions, including as a singular shrub in dry, sun-exposed dirt piles near recently disturbed agriculture fields, but also growing as extensive networks of vines, climbing up acacia trees in semishaded, cooler riparian areas. Therefore, our model results should be interpreted with some caution, because Pearson et al. (2007) aptly stress that such assessments with limited occurrence data sets should be viewed as identifying regions with similar environmental conditions to where the species in question is known to occur, and not as predicting actual limits to the range of that species.

Switching the model occurrence data sets, i.e., training the model with the 50 participatory mapping occurrence points and testing the model with the 18 field collected points, resulted in additional high AUC values and correct classification percentages, but model predictions were noticeably restricted to areas with existing rubber vine occurrence points. Furthermore, model predictor importance shifted to topographic variables and different anthropogenic variables, i.e., elevation and distance to settlements, both of which had little to no influence in the other model runs. This is likely because of the close proximity of rubber vine occurrence points identified in the participatory mapping activities to the respective villages of participating pastoralists. This spatial autocorrelation may account for the noticeable drop in the sensitivity value when applying the model trained on these data to the field collected occurrence points. Additionally, this may explain why elevation is a dominant driver for the model, based on the villages and participatory mapping points existing at much lower elevations compared to the field collected data that were much further out from the settlements. This process revealed the participatory mapping data set to have noticeable sampling bias. The occurrence points were too spatially autocorrelated to train a model with, but provided a useful preliminary validation data set and further highlights the importance of stratifying occurrence point sampling as much as possible, even within a participatory convenience sampling framework.

We overlaid the rubber vine habitat suitability map with the MESS map produced by Maxent to further assess relative confidence in the model output and determine locations for future targeted surveying attempts. The MESS output revealed locations with novel environmental conditions, e.g., conditions that rest outside the range covered by the presence and background locations used to develop the model (Fig. 4; Elith et al. 2010). Crall et al. (2013) provide strong support for the use of an iterative sampling design facilitated by MESS map assessment, finding models trained on targeted sampling data to perform better than those generated from nontargeted sampling data. Our study used such an approach, with the novel application of local pastoral knowledge as the targeted sampling training and test data sets. It would prove difficult to map rubber vine solely with pastoral knowledge. Conducting participatory field sampling across such a vast landscape would be time and labor intensive, in addition to participatory mapping activities potentially overlooking a number of rubber vine occurrences and thus limiting early detection efforts. Our model effectively relayed rubber vine habitat suitability in relation to consistent environmental conditions linked with rivers and stream systems across the study area, with the addition of the MESS output highlighting where topographic, environmental, and anthropogenic characteristics are novel compared to the sampled region. The southern Gabi zone where our field data were collected, has the highest average annual rainfall for the Afar region at approximately 510-1032 mm (Sonneveld et al. 2010). Distinct environmental characteristics linked with average annual precipitation patterns and elevation exist across the Afar region as one moves south to north, with the landscape becoming increasingly arid, with greatly reduced rainfall and dramatically higher elevations. These distinct environmental changes may act as a major limiting factor to rubber vine spread northward, but the species is noted to handle a diverse range of environmental conditions (McFadyen and Harvey 1990, Kriticos et al. 2003). We cannot say definitively that the predictions beyond the initial spatial extent north of the model occurrence points are robust, but these results show with great certainty the high suitability of rubber vine habitat immediately down-river of the collected occurrence points and the great potential for further expansion along the Awash River and its tributaries, thus providing an important early warning and monitoring tool for this recently established species and highlighting areas in need of additional field assessment.

\section{Next steps}

Necessary next steps include validation of the model outputs with pastoralists and conducting additional participatory, targeted surveying, in addition to enacting a more systematic or random sampling approach to give a better picture of model validity. Furthermore, having a female translator that speaks Afar and Amharic would better facilitate the recruitment of women for these future activities. Moreover, beginning a dialogue with local and regional government land managers and international aid organizations working in Afar around these study results could be an important step toward addressing rubber vine. This includes assessing rubber vine invasion through an environmental security framing, to better understand the connections between environment and conflict in the region (Dalby 2002). Political and cultural conflicts stemming from poorly designed development strategies beginning in the 1950s and the remnants of the EritreanEthiopian War (1998-2000) have resulted in ongoing instability in the region. Afar pastoralists have already noted a lack of forage and fodder for their livestock and now need to travel further, resulting in increased conflicts with predators and Somali clans. Expansion of rubber vine could further exacerbate this already unstable situation. This work further supports the idea that invasive species habitat suitability modeling should be an iterative 
process (Stohlgren and Schnase 2006, Crall et al. 2013), one we suggest could engage in collaboration and knowledge integration at all steps, beyond researchers and land managers, which is the current trend in species distribution modeling literature. Moreover, this work reveals the value of working closely with and empowering local communities that have detailed knowledge of the landscapes they inhabit and newly established non-native species, to enhance and facilitate more effective and holistic risk assessment approaches including early detection and targeted surveying and monitoring efforts.

\section{CONCLUSION}

Invasive plants have an array of detrimental impacts on ecosystems and rural livelihoods in arid and semiarid regions around the world. Successful control of invasive species depends on early detection and rapid response, which we suggest is best achieved through meaningful collaboration with local communities that live on the affected landscapes. This study demonstrated the utility of integrating local pastoral knowledge with species distribution modeling for invasion risk assessment studies, highlighting the growing threats posed by invasive rubber vine to the Afar region. Our model was highly accurate, as evidenced by the assessment metrics. Primarily the model highlights the growing risk rubber vine poses to the Afar region, with suitable habitat extending downstream of its current distribution in the middle Awash River basin. Local pastoral knowledge provided important context for its rapid expansion because of acute changes in seasonality and extensive habitat alteration. Moreover, this knowledge relayed immediate threats posed to a number of native tree species that provide critical provisioning ecosystem services to pastoralists. To date, little attention seems to have been paid to rubber vine in Ethiopia by government agencies, academic research institutions, and nonprofit organizations alike. As important as our quantitative evidence of the distribution of rubber vine, our qualitative participatory methods provided an important narrative of the current distribution and expanding potential for negative influence of this invasive plant on local livelihoods. Local pastoral knowledge thus acts as a critical early warning system that can enhance existing risk assessment approaches including early detection and targeted surveying of recently established invasive species.

Responses to this article can be read online at: http://www.ecologyandsociety.org/issues/responses. php/7988

\section{Acknowledgments:}

This study was conducted through the Natural Resource Ecology Laboratory at Colorado State University and the U.S. Geological Survey (USGS) Fort Collins Science Center. Funding for this research was provided by the National Needs Fellowship program of the National Institute of Food and Agriculture, U.S. Department of Agriculture, U.S. Geological Survey, and the National Science Foundation. We would like to thank all of the pastoral communities that participated in this study, for contributing their detailed knowledge of the landscape. Special thanks to Seyed Mohammed whose tireless efforts and constant humor, in addition to his contributions as guide, translator, and research assistant, were invaluable to the success of this project. Additional thanks to the two anonymous reviewers, journal editors, and Daniel Manier from the USGS Fort Collins Science Center who provided valuable comments and discussion that have greatly improved this manuscript. Any use of trade product, or firm names is for descriptive purposes only and does not imply endorsement by the $U$. S. Government or Colorado State University.

\section{LITERATURE CITED}

Augustus, G. D. P. S., M. Jayabalan, and G. J. Seiler. 2000. Cryptostegia grandiflora - a potential multi-use crop. Industrial Crops and Products 11:59-62. http://dx.doi.org/10.1016/ S0926-6690(99)00036-9

Allan, J. D. 2004. Landscapes and riverscapes: the influence of land use on stream ecosystems. Annual Review of Ecology, Evolution, and Systematics 35:257-284. http://dx.doi.org/10.1146/ annurev.ecolsys.35.120202.110122

Andrew, M. E., and S. L. Ustin. 2009. Habitat suitability modelling of an invasive plant with advanced remote sensing data. Diversity and Distributions 15:627-640. http://dx.doi.org/10.1111/ j.1472-4642.2009.00568.x

Armitage, D., F. Berkes, A. Dale, E. Kocho-Schellenberg, and E. Patton. 2011. Co-management and the co-production of knowledge: learning to adapt in Canada's Arctic. Global Environmental Change 21:995-1004. http://dx.doi.org/10.1016/j. gloenvcha.2011.04.006

Awulachew, S. B., A. D. Yilma, M. Loulseged, W. Loiskandl, M. Ayana, and T. Alamirew. 2007. Water resources and irrigation development in Ethiopia. Working Paper 123, International Water Management Institute, Colombo, Sri Lanka.

Ayanu, Y., A. Jentsch, D. Müller-Mahn, S. Rettberg, C. Romankiewicz, and T. Koellner. 2015. Ecosystem engineer unleashed: Prosopis juliflora threatening ecosystem services? Regional Environmental Change 15:155-167. http://dx.doi. org/10.1007/s10113-014-0616-X

Bahru, T., Z. Asfaw, and S. Demissew. 2012. Indigenous knowledge of plant species of material culture (construction, traditional arts and handicrafts) used by the Afar and Oromo nations in and around the Awash National Park, Ethiopia. Global Journal of Human Social Science Geography and Environmental Geosciences 12(11):1-23.

Ballard, H. L., M. E. Fernandez-Gimenez, and V. E. Sturtevant. 2008. Integration of local ecological knowledge and conventional science: a study of seven community-based forestry organizations in the USA. Ecology and Society 13(2):37. [online] URL: http:// www.ecologyandsociety.org/vol13/iss2/art37/

Behnke, R., and C. Kerven. 2013. Counting the costs: replacing pastoralism with irrigated agriculture in the Awash Valley. Pages 57-70 in A. Catley, J. Lind, and I. Scoones, editors. Pastoralism and development in Africa: dynamic changes at the margins. Routledge, London, UK.

Berkes, F., and M. K. Berkes. 2009. Ecological complexity, fuzzy logic, and holism in indigenous knowledge. Futures 41:6-12. http://dx.doi.org/10.1016/j.futures.2008.07.003 
Bradley, B. A., D. M. Blumenthal, R. Early, E. D. Grosholz, J. J. Lawler, L. P. Miller, C. J. B. Sorte, C. M. D’Antonio, J. M. Diez, J. S. Dukes, I. Ibanez, and J. D. Olden. 2012. Global change, global trade, and the next wave of plant invasions. Frontiers in Ecology and the Environment 10(1):20-28. http://dx.doi.org/10.1890/110145

Bradley, B. A., and J. F. Mustard. 2006. Characterizing the landscape dynamics of an invasive plant and risk of invasion using remote sensing. Ecological Applications 16:1132-1147. http://dx. doi.org/10.1890/1051-0761(2006)016[1132:CTLDOA]2.0.CO;2

Brown, J. R., J. C. Scanlan, and J. G. McIvor. 1998. Competition by herbs as a limiting factor in shrub increase: a test with different growth forms. Journal of Vegetation Science 9(6):829-836. http:// dx.doi.org/10.2307/3237048

Catley, A., J. Lind, and I. Scoones, editors. 2013. Pastoralism and development in Africa: dynamic changes at the margins. Routledge, London, UK.

Cook, D. R., G. W. Campbell, and A. R. Meldrum. 1990. Suspected Cryptostegia grandiflora (rubber vine) poisoning in horses. Australian Veterinary Journal 67(9):344. http://dx.doi. org/10.1111/j.1751-0813.1990.tb07825.x

Crall, A. W., C. S. Jarnevich, B. Panke, N. Young, M. Renz, and J. Morisette. 2013. Using habitat suitability models to target invasive plant species surveys. Ecological Applications 23 (1):60-72. http://dx.doi.org/10.1890/12-0465.1

Crowl, T. A., T. O. Crist, R. R. Parmenter, G. Belovsky, and A. E. Lugo. 2008. The spread of invasive species and infectious disease as drivers of ecosystem change. Frontiers in Ecology and the Environment 6(5):238-246. http://dx.doi.org/10.1890/070151

Dalby, S. 2002. Environmental security. University of Minnesota Press, Minneapolis, Minnesota, USA.

Davies, J., and R. Bennett. 2007. Livelihood adaptation to risk: constraints and opportunities for pastoral development in Ethiopia's Afar region. Journal of Development Studies 43 (3):490-511. http://dx.doi.org/10.1080/00220380701204422

Dormann, C. F., J. Elith, S. Bacher, C. Buchmann, G. Carl, G. Carré, J. R. García Marquéz, B. Gruber, B. Lafourcade, P. J. Leitão, T. Münkemüller, C. McClean, P. E. Osborne, B. Reineking, B. Schröder, A. K. Skidmore, D. Zurell, and S. Lautenbach. 2013. Collinearity: a review of methods to deal with it and a simulation study evaluating their performance. Ecography 36(1):27-46. http://dx.doi.org/10.1111/j.1600-0587.2012.07348.x

Dubale, A. 2006. Impacts of Prosopis juliflora invasion and control using charcoal production in Afar National Regional State, Ethiopia. Thesis, University of Wales, Bangor, UK.

Elith, J., M. Kearney, and S. Phillips. 2010. The art of modelling range-shifting species. Methods in Ecology and Evolution 1:330-342. http://dx.doi.org/10.1111/j.2041-210X.2010.00036.x

Elith, J., S. J. Phillips, T. Hastie, M. Dudík, Y. En Chee, and C. J. Yates. 2011. A statistical explanation of MaxEnt for ecologists. Diversity and Distributions 17:43-57. http://dx.doi.org/10.1111/ j.1472-4642.2010.00725.X

ESRI. 2011. ArcGIS Desktop: Release 10. Environmental Systems Research Institute, Redlands, California, USA.
Ethiopian Society of Animal Production (ESAP). 2007. Pastoral livestock systems: opportunities and challenges as a livelihood strategy. Tamarat Degefa and Fekede Feyissa, editors. Proceedings of the 15th Annual conference of the Ethiopian Society of Animal Production (ESAP) held in Addis Ababa, Ethiopia, October 4-6, 2007 Part I Plenary Session. ESAP, Addis Ababa.

Evangelista, P. H., S. Kumar, T. J. Stohlgren, C. S. Jarnevich, A. W. Crall, J. B. Norman III, and D. T. Barnett. 2008. Modelling invasion for a habitat generalist and a specialist plant species. Diversity and Distributions 14:808-817. http://dx.doi.org/10.1111/ j.1472-4642.2008.00486.x

Evangelista, P. H., T. J. Stohlgren, J. T. Morisette, and S. Kumar. 2009. Mapping invasive Tamarisk (Tamarix): a comparison of single-scene and time-series analyses of remotely sensed data. Remote Sensing 1:519-533. http://dx.doi.org/10.3390/rs1030519

Evans, J., J. Oakleaf, S. Cushman, and D. Theobald. 2014. An ArcGIS toolbox for surface gradient and geomorphometric modeling, version 2.0-0. The Nature Conservancy and University of Wyoming, Laramie, Wyoming, USA. [online] URL: http:// evansmurphy.wix.com/evansspatial\#! arcgis-gradient-metrics-toolbox/ $\underline{\text { crro }}$

Fernández-Giménez, M. E., and F. F. Estaque. 2012. Pyrenean pastoralists' ecological knowledge: documentation and application to natural resource management and adaptation. Human Ecology 40(2):287-300. http://dx.doi.org/10.1007/ s10745-012-9463-X

Franklin, J. 2010. Mapping species distributions: spatial inference and prediction. Cambridge University Press, Cambridge, Massachusetts, USA. http://dx.doi.org/10.1017/cbo9780511810602

Gagnon, C. A., and D. Berteaux. 2009. Integrating traditional ecological knowledge and ecological science: a question of scale. Ecology and Society 14(2):19. [online] URL: http://www. ecologyandsociety.org/vol14/iss2/art19/

García-Llorente, M., B. Martín-López, J. A. González, P. Alcorlo, and C. Montes. 2008. Social perceptions of the impacts and benefits of invasive alien species: implications for management. Biological Conservation 141:2969-2983. http://dx.doi.org/10.1016/ j.biocon.2008.09.003

Getachew, K. N. 2001. Among the pastoral Afar in Ethiopia: tradition, continuity and socio-economic change. International Books, Utrecht, The Netherlands.

Getachew, S., S. Demissew, and T. Woldemariam. 2012. Allelopathic effects of the invasive Prosopis juliflora (Sw.) DC. on selected native plant species in Middle Awash, Southern Afar Rift of Ethiopia. Management of Biological Invasions 3(2):105-114. http://dx.doi.org/10.3391/mbi.2012.3.2.05

Giday, M., and T. Teklehaymanot. 2013. Ethnobotanical study of plants used in management of livestock health problems by Afar people of Ada'ar District, Afar Regional State, Ethiopia. Journal of Ethnobiology and Ethnomedicine 9:8-17. http://dx.doi. org/10.1186/1746-4269-9-8

Grice, A. C. 1996. Seed production, dispersal and germination in Cryptostegia grandiflora and Ziziphus mauritiana, two invasive shrubs in tropical woodlands of northern Australia. Australian Journal of Ecology 21(3):324-331. http://dx.doi.org/10.1111/ j.1442-9993.1996.tb00615.X 
Grice, A. 1997. Post-fire regrowth and survival of the invasive tropical shrubs Cryptostegia grandiflora and Ziziphus mauritiana. Austral Ecology 22:49-55. http://dx.doi.org/10.1111/j.1442-9993.1997. tb00640.x

Hejda, M., P. Pyšek, and V. Jarošík. 2009. Impacts of invasive plants on the species richness, diversity and the composition of invaded communities. Journal of Ecology 97(3):393-403. http:// dx.doi.org/10.1111/j.1365-2745.2009.01480.x

Hernandez, P. A., C. H. Graham, L. L. Master, and D. L. Albert. 2006. The effect of sample size and species characteristics on performance of different species distribution modeling methods. Ecography 29(5):773-785. http://dx.doi.org/10.1111/ j.0906-7590.2006.04700.x

Hirzel, A. H., and R. Arlettaz. 2003. Modeling habitat suitability for complex species distributions by environmental-distance geometric mean. Environmental Management 32(5):614-623. http://dx.doi.org/10.1007/s00267-003-0040-3

Hulme, P. E. 2006. Beyond control: wider implications for the management of biological invasions. Journal of Applied Ecology 43:835-847. http://dx.doi.org/10.1111/j.1365-2664.2006.01227.x

Hulme, P. E. 2009. Trade, transport and trouble: managing invasive species pathways in an era of globalization. Journal of Applied Ecology 46(1):10-18. http://dx.doi.org/10.1111/ j.1365-2664.2008.01600.x

Huntington, H. P. 1998. Observations on the utility of the semidirective interview for documenting traditional ecological knowledge. Arctic 51:237-242. http://dx.doi.org/10.14430/ $\underline{\operatorname{arctic} 1065}$

International Union for Conservation of Nature (IUCN). 2000. IUCN Guidelines for the Prevention of Biodiversity Loss caused by Alien Invasive Species. Information Paper from the Fifth Meeting of the Conference of the Parties to the Convention on Biological Diversity, approved by the $51^{\text {st }}$ Meeting of Council, February 2000, Gland, Swizerland.

Invasive Species Compendium. 2014. Cryptostegia grandiflora datasheet. Invasive Species Compendium, Wallingford, UK. [online] URL: http://www.cabi.org/isc/datasheet/16378

Jarnevich, C. S., P. Evangelista, T. J. Stohlgren, and J. Morisette. 2011. Improving national-scale invasion maps: Tamarisk in the Western United States. Western North American Naturalist 71 (2):164-175. http://dx.doi.org/10.3398/064.071.0204

Jarnevich, C. S., T. R. Holcombe, E. M. Bella, M. L. Carlson, G. Graziano, M. Lamb, S. S. Seefeldt, and J. Morisette. 2014. Crossscale assessment of potential habitat shifts in a rapidly changing climate. Invasive Plant Science and Management 7:491-502. http:// dx.doi.org/10.1614/IPSM-D-13-00071.1

Kaplan, H., A. van Niekerk, J. J. Le Roux, D. M. Richardson, and J. R. U. Wilson. 2014. Incorporating risk mapping at multiple spatial scales into eradication management plans. Biological Invasions 16(3):691-703. http://dx.doi.org/10.1007/s10530-013-0611$\underline{\mathrm{Z}}$

Kapler, E. J., J. R. Thompson, and M. P. Widrlechner. 2012. Assessing stakeholder perspectives of invasive plants to inform risk analysis. Invasive Plant Science and Management 5 (2):194-208. http://dx.doi.org/10.1614/ipsm-d-11-00067.1
Kebede, F., A. Bekele, P. D. Moelman, and P. H. Evangelista. 2014. Predicting seasonal habitat suitability for the critically endangered African wild ass in the Danakil, Ethiopia. African Journal of Ecology 52(4):533-542. http://dx.doi.org/10.1111/ aje. 12159

Kebede, F., P. D. Moelman, A. Bekele, and P. H. Evangelista. 2012. Endangered Grevy's zebra in the Alledeghi Wildlife Reserve, Ethiopia: species distribution modeling for the determination of optimum habitat. Endangered Species Research 17:237-244. http://dx.doi.org/10.3354/esr00416

Khanum, R., A. S. Mumtaz, and S. Kumar. 2013. Predicting impacts of climate change on medicinal asclepiads of Pakistan using Maxent modeling. Acta Oecologica 49:23-31. http://dx.doi. org/10.1016/j.actao.2013.02.007

Kriticos, D. J., R. W. Sutherst, J. R. Brown, S. W. Adkins, and G. F. Maywald. 2003. Climate change and biotic invasions: a case history of a tropical woody vine. Biological Invasions 5:145-165. http://dx.doi.org/10.1023/A:1026193424587

Kull, C. A., C. M. Shackleton, P. J. Cunningham, C. Ducatillion, J. M. Dufour-Dror, K. J. Esler, J. B. Friday, A. C. Gouveia, A. R. Griffin, E. Marchante, S. J. Midgley, A. Pauchard, H. Rangan, D. M. Richardson, T. Rinaudo, J. Tassin, L. S. Urgenson, G. P. von Maltitz, R. D. Zenni, and M. J. Zylstra. 2011. Adoption, use and perception of Australian acacias around the world. Diversity and Distributions 17:822-836. http://dx.doi.org/10.1111/ j.1472-4642.2011.00783.X

Lindgren, C. J. 2012. Biosecurity policy and the use of geospatial predictive tools to address invasive plants: updating the risk analysis toolbox. Risk Analysis 32(1):9-15. http://dx.doi. org/10.1111/j.1539-6924.2011.01642.x

Lowe, S., M. Browne, S. Boudjelas, and M. De Poorter. 2000. 100 of the World's worst invasive alien species: a selection from the Global Invasive Species Database. The Invasive Species Specialist Group (ISSG), Species Survival Commission (SSC) of the World Conservation Union (IUCN), Auckland, New Zealand, USA.

Luizza, M. W., H. Young, C. Kuroiwa, P. Evangelista, A. Worede, R. W. Bussmann, and A. Weimer. 2013. Local knowledge of plans and their uses among women in the Bale Mountains, Ethiopia. Ethnobotany Research and Applications 11:315-339.

Mack, R. N., and M. Erneberg. 2002. The United States naturalized flora: largely the product of deliberate introductions. Annals of the Missouri Botanical Garden 89:176-189. http://dx. doi.org/10.2307/3298562

McFadyen, R. E., and G. J. Harvey. 1990. Distribution and control of rubber vine, Cryptostegia grandiflora, a major weed in northern Queensland. Plant Protection Quarterly 5(4):152-155.

Mekonnen, Y. 1994. A survey of plants (potentially) toxic to livestock in the Ethiopia flora. Sinet, an Ethiopian Journal of Science 17(1):9-32.

Morgan, D. L. 1997. Focus groups as qualitative research. Second edition. Sage Books, Thousand Oaks, California, USA.

Morisette, J. T., C. S. Jarnevich, T. R. Holcombe, C. B. Talbert, D. Ignizio, M. K. Talbert, C. Silva, D. Koop, A. Swanson, and N. E. Young. 2013. VisTrails SAHM: visualization and workflow 
management for species habitat modeling. Ecography 36 (2):129-135. http://dx.doi.org/10.1111/j.1600-0587.2012.07815.x

Mwangi, E., and B. Swallow. 2008. Prosopis juliflora invasion and rural livelihoods in the Lake Baringo area of Kenya. Conservation and Society 6(2):130-140. http://dx.doi.org/10.4103/0972-4923.49207

Nadasdy, P. 1999. The politics of Tek: power and the "integration" of knowledge. Arctic Anthropology 36(1/2):1-18.

National Weeds Strategy Executive Committee. 2001. Weeds of national significance: rubber vine (Cryptostegia grandiflora): strategic plan. National Weeds Strategy Executive Committee, Launceston, Tasmania, Australia.

Oba, G. 2013. The sustainability of pastoral production in Africa. Pages 29-36 in A. Catley, J. Lind, and I. Scoones, editors. Pastoralism and development in Africa: dynamic changes at the margins. Routledge, London, UK.

Patton, M. Q. 2002. Qualitative research and evaluation methods Third edition. Sage, Thousand Oaks, California, USA.

Pearson, R. G., C. J. Raxworthy, M. Nakamura, and A. T. Peterson. 2007. Predicting species distributions from small numbers of occurrence records: a test case using cryptic geckos in Madagascar. Journal of Biogeography 34:102-117. http://dx. doi.org/10.1111/j.1365-2699.2006.01594.x

Pejchar, L., and H. A. Mooney. 2009. Invasive species, ecosystem services and human well-being. Trends in Ecology and Evolution 24:497-504. http://dx.doi.org/10.1016/j.tree.2009.03.016

Peterson, A. T., J. Soberon, R. G. Pearson, R. P. Anderson, E. Martinez-Meyer, M. Nakamura, and M. B. Araujo. 2011. Ecological niches and geographic distributions. Princeton University Press, Princeton, New Jersey, USA.

Pfeiffer, J. M., and R. J. Butz. 2005. Assessing cultural and ecological variation in ethnobiological research: the importance of gender. Journal of Ethnobiology 25(2):240-278. http://dx.doi. org/10.2993/0278-0771(2005)25[240:acaevi] 2.0.co;2

Phillips, S. J., R. P. Anderson, and R. E. Schapire. 2006. Maximum entropy modeling of species geographic distributions. Ecological Modelling 190:231-259. http://dx.doi.org/10.1016/j.ecolmodel.2005.03.026

Pimentel, D., R. Zuniga, and D. Morrison 2005. Update on the environmental and economic costs associated with alien-invasive species in the United States. Ecological Economics 52:273-288. http://dx.doi.org/10.1016/j.ecolecon.2004.10.002

Powell, M. R. 2004. Risk assessment for invasive plant species. Weed Technology 18(sp1):1305-1308. http://dx.doi.org/10.1614/0890-037X (2004)018[1305:RAFIPS]2.0.CO;2

Radford, I. J., A. C. Grice, B. N. Abbott, D. M. Nicholas, and L. Whiteman. 2008. Impacts of changed fire regimes on tropical riparian vegetation invaded by an exotic vine. Australian Journal of Ecology 33:151-167. http://dx.doi.org/10.1111/j.1442-9993.2007.01803. $\underline{\mathrm{X}}$

Rodríguez-Estrella, R., J. J. P. Navarro, B. Granados, and L. Rivera. 2010. The distribution of an invasive plant in a fragile ecosystem: the rubber vine (Cryptostegia grandiflora) in oases of the Baja California peninsula. Biological Invasions 12:3389-3393. http://dx.doi.org/10.1007/s10530-010-9758-Z
Rota, A., and S. Sperandini. 2009. Livestock and pastoralists. Livestock Thematic Papers: Tools for Project Design. International Fund for Agricultural Development, Rome, Italy. [online] URL: http://www.ifad.org/lrkm/factsheet/pastoralists. pdf

Shackleton, S., D. Kirby, and J. Gambiza. 2011. Invasive plants friends or foes? Contribution of prickly pear (Opuntia ficusindica) to livelihoods in Makana Municipality, Eastern Cape, South Africa. Development Southern Africa 28(2):177-193. http:// dx.doi.org/10.1080/0376835X.2011.570065

Sonneveld, B. G. J. S., M. A. Keyzer, K. Georgis, S. Pande, A. Seid Ali, and A. Takele. 2009. Following the Afar: using remote tracking systems to analyze pastoralists' trekking routes. Journal of Arid Environments 73:1046-1050. http://dx.doi.org/10.1016/j. jaridenv.2009.05.001

Sonneveld, B. G. J. S., S. Pande, K. Georgis, M. A. Keyzer, A. Seid Ali, and A. Takele. 2010. Land degradation and overgrazing in the Afar region, Ethiopia: a spatial analysis. Pages 97-109 in P. Zdruli, M. Pagliai, S. Kapur, and A. Faz Cano, editors. Land degradation and desertification: assessment, mitigation and remediation. Springer, London, UK. http://dx.doi. org/10.1007/978-90-481-8657-0 8

Stohlgren, T. J., P. Ma, S. Kumar, M. Rocca, J. T. Morisette, C. S. Jarnevich, and N. Benson. 2010. Ensemble habitat mapping of invasive plant species. Risk Analysis 30(2):224-235. http://dx.doi. org/10.1111/j.1539-6924.2009.01343.x

Stohlgren, T. J., and J. L. Schnase. 2006. Risk analysis for biological hazards: what we need to know about invasive species. Risk Analysis 26(1):163-173. http://dx.doi.org/10.1111/ j.1539-6924.2006.00707.x

Thuiller, W., D. M. Richardson, and G. F. Midgley. 2007. Will climate change promote alien plant invasions? Pages 197-211 in W. Nentwig, editor. Biological invasions. Ecological studies, Vol. 193. Springer-Verlag, Berlin, Germany. http://dx.doi. org/10.1007/978-3-540-36920-2_12

Tikssa, M., T. Bekele, and E. Kelbessa. 2010. Plant community distribution and variation along the Awash River corridor in the main Ethiopian rift. African Journal of Ecology 48:21-28. http:// dx.doi.org/10.1111/j.1365-2028.2009.01116.x

Tomley, A. J. 1995. The biology of Australian weeds. 26. Cryptostegia grandiflora R. Br. Plant Protection Quarterly 10 (4):122-130.

Tsegaye, D., S. R. Moe, P. Vedeld, E. Aynekulu. 2010. Land-use/ cover dynamics in northern Afar rangelands, Ethiopia. Agriculture, Ecosystems and Environment 139:174-180. http://dx. doi.org/10.1016/j.agee.2010.07.017

Tucker, C. J. 1979. Red and photographic infrared linear combinations for monitoring vegetation. Remote Sensing of Environment 8:127-150. http://dx.doi.org/10.1016/0034-4257(79) 90013-0

Urgenson, L. S., H. E., Prozesky, and K. J. Esler. 2013. Stakeholder perceptions of an ecosystem service approach to clearing invasive alien plants on private land. Ecology and Society 18(1):26. http://dx.doi.org/10.5751/es-05259-180126 
Vilà, M., C. Basnou, P. Pyšek, M. Josefsson, P. Genovesi, S. Gollasch, W. Nentwig, S. Olenin, A. Roques, D. Roy, P. E. Hulme, and DAISE partners. 2010. How well do we understand the impacts of alien species on ecosystem services? A pan-European, cross-taxa assessment. Frontiers in Ecology and the Environment 8:135-144. http://dx.doi.org/10.1890/080083

Vitousek, P. M. 1990. Biological invasions and ecosystem processes: towards an integration of population biology and ecosystem studies. Oikos 57:7-13. http://dx.doi.org/10.2307/3565731

Wakie, T. T., P. H. Evangelista, C. S. Jarnevich, and M. Laituri. 2014. Mapping current and potential distribution of non-native Prosopis juliflora in the Afar Region of Ethiopia. PLOS ONE 9 (11):e112854. http://dx.doi.org/10.1371/journal.pone.0112854

Wisz, M. S., R. J. Hijmans, J. Li, A. T. Peterson, C. H. Graham, A. Guisan, and NCEAS Predicting Species Distribution Working Group. 2008. Effects of sample size on the performance of species distribution models. Diversity and Distributions 14:763-773. http://dx.doi.org/10.1111/j.1472-4642.2008.00482.x

With, K. A. 2004. Assessing the risk of invasive spread in fragmented landscapes. Risk Analysis 24(4):803-815. http://dx. doi.org/10.1111/j.0272-4332.2004.00480.X

Yohannes, T., T. Awas, and S. Demissew. 2011. Survey and documentation of the potential and actual invasive alien plant species and other biological threats to biodiversity in Awash National Park, Ethiopia. Management of Biological Invasions 2:3-14. http://dx.doi.org/10.3391/mbi.2011.2.1.01 
Appendix 1. Focus group open-ended interview questions.

Location

Date

Land Cover Category (farmland, grassland, rangeland; if more than one, answer for the category where Prosopis is of most concern)

Study Site Prosopis Density Class (Scattered (less than 20\%), Moderate (20-40\%), Dense (over 40\%))

\section{Demographics (list for all respondents in focus group)}

1. Gender: Male Female

2. Age: $15-20 \quad 21-25 \quad 26-30 \quad 31-35 \quad 36-40 \quad 41-45 \quad 46-50 \quad 51-55 \quad 56-60 \quad 60+$

3. Primary Occupation (Pastoralist, Agro-pastoralist, Farmer)

4. Were you born here? If not, when and why did you move here?

5. How many people are in your household?

6. Do you have children? Hes Now many?

\section{Landscape-Scale Changes}

1. Are there changes to nature, which you have observed in your community during your lifetime, for example, changes in plants, water, soils, or wildlife?

2. What do you think caused this change? 
3. Has the timing of the seasons changed over time?

Seasons: Note which have changed

\begin{tabular}{l|l|l|l|l|l|l} 
Early wet & Wet & Late wet & Early dry & Dry & Late dry \\
\hline & & & & &
\end{tabular}

4. If yes, how has it changed?

5. When do the rains come?

Jan Feb Mar Apr May Jun Jul Aug Sep Oct Nov Dec

6. Is it the same time every year?
7. If no to $\# 6$, describe how it varies (e.g. early, later, shorter, longer)?

8. Is the amount of rain different?

9. Does flooding and/or drought happen more or less, or are less predictable?

10. Does this affect your livestock and/or crops?

11. Does this affect wildlife?

\section{Plants and Animals}

1. Do you use plants for medicine or go to the doctor?

2. Are there plants that you consider bad? Are any of these new to the region?

3. Are any of these plants taking the place of useful plants and cannot be controlled? 
4. What are the most important plants to you?

5. Why are they important?

6. What type of wood do you prefer to burn?

7. What wildlife are beneficial to you and why?

8. What wildlife are harmful and why?

9. Is there anything we didn't ask regarding plants and animals in the area that you'd like to share? 
Appendix 2. List of Landsat 8 cloudless scenes used in participatory mapping activities.

\begin{tabular}{|l|l|l|}
\hline \multicolumn{3}{|c|}{ Available Cloudless Landsat 8 Scenes } \\
\hline Path & Row & Scene Date \\
\hline 167 & 53 & $12 / 10 / 13$ \\
\hline 167 & 54 & $12 / 01 / 13$ \\
\hline 168 & 53 & $12 / 10 / 13$ \\
\hline
\end{tabular}


Appendix 3. SAHM Covariate Correlation and Selection Matrix.

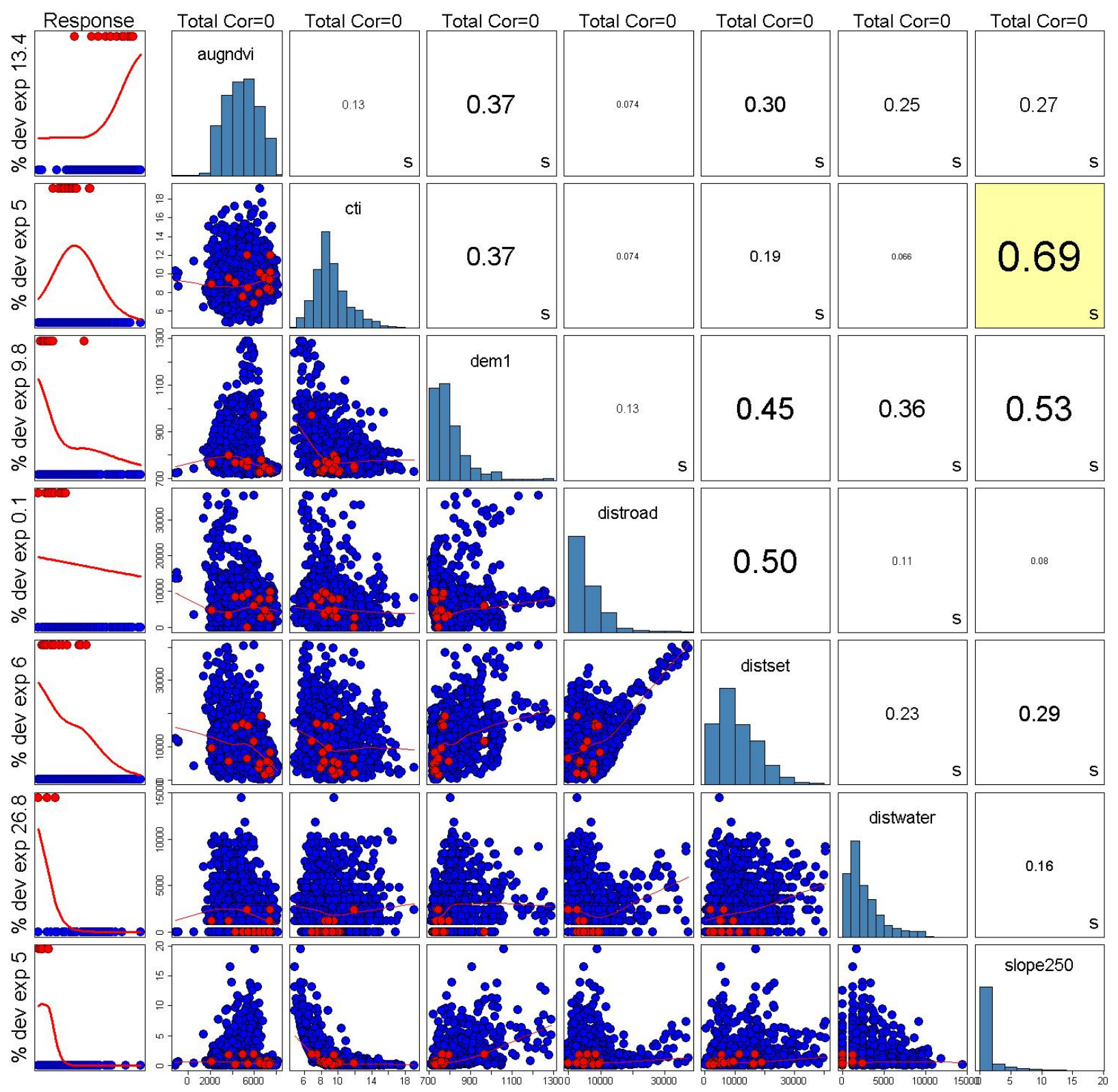


Appendix 4. Most important native trees used by Afar pastoralists for firewood. Trees listed in order of importance (determined by focus group participants) with scientific name, local Afar name and all provisioning ecosystem services provided (uses) listed.

\begin{tabular}{|c|c|c|c|}
\hline Scientific Name & Afar Name & Uses & Notes \\
\hline Acacia nilotica & Keselto & $\begin{array}{l}\text { Firewood, charcoal, } \\
\text { construction, forage, } \\
\text { medicinal, other (shade). }\end{array}$ & $\begin{array}{l}\text { Preferred firewood and } \\
\text { charcoal source } \\
\text { (including high-end } \\
\text { hookah charcoal). Bole } \\
\text { and branches used in } \\
\text { house construction. } \\
\text { Pods, leaves and flowers } \\
\text { forage source for } \\
\text { livestock and wildlife. } \\
\text { Bark ground, mixed } \\
\text { with water, and applied } \\
\text { to snake bite wounds. }\end{array}$ \\
\hline Acacia senegal & Adado & $\begin{array}{l}\text { Firewood, charcoal, } \\
\text { construction, food, } \\
\text { forage. }\end{array}$ & $\begin{array}{l}\text { Number one charcoal } \\
\text { source. Provides forage } \\
\text { for livestock (especially } \\
\text { camels and goats). Used } \\
\text { to build fences to protect } \\
\text { livestock. Produces } \\
\text { edible gum that is mixed } \\
\text { with camel's milk and } \\
\text { consumed. }\end{array}$ \\
\hline $\begin{array}{l}\text { Combretum } \\
\text { aculeatum }\end{array}$ & Kilaito & $\begin{array}{l}\text { Firewood, charcoal, } \\
\text { medicinal, cosmetic, } \\
\text { forage, fodder. }\end{array}$ & $\begin{array}{l}\text { Leaves, pods and } \\
\text { flowers forage source } \\
\text { for livestock and } \\
\text { wildlife. Leaves cut and } \\
\text { gathered as fodder for } \\
\text { livestock. Wood is } \\
\text { burned and a person } \\
\text { allows the smoke to } \\
\text { cover their body for skin } \\
\text { health/beautification. }\end{array}$ \\
\hline Acacia tortilis & Ehebto & $\begin{array}{l}\text { Firewood, charcoal, } \\
\text { construction, forage, } \\
\text { other (shade). }\end{array}$ & $\begin{array}{l}\text { Bole and branches used } \\
\text { in used in house } \\
\text { construction. Pods, } \\
\text { leaves and flowers } \\
\text { provide forage for } \\
\text { livestock and wildlife. }\end{array}$ \\
\hline Acacia mellifera & Maka'arto & Firewood, charcoal, & Provides forage for \\
\hline
\end{tabular}




\begin{tabular}{|c|c|c|c|}
\hline & & construction, forage. & $\begin{array}{l}\text { livestock (especially } \\
\text { camels and goats) and } \\
\text { wildlife. Used to build } \\
\text { houses and fences to } \\
\text { protect livestock. }\end{array}$ \\
\hline Cordia spp. & Mederto & $\begin{array}{l}\text { Firewood, construction, } \\
\text { food, other } \\
\text { (walking/herding/fighting } \\
\text { sticks and rope). }\end{array}$ & $\begin{array}{l}\text { Preferred firewood } \\
\text { source but also used to } \\
\text { start fires (sticks rubbed } \\
\text { together). Used in } \\
\text { construction of } \\
\text { traditional Afar homes } \\
\text { called } \text { Afar arri or } \text { arri } \\
\text { orburra. Preferred } \\
\text { source of } \\
\text { walking/herding/fighting } \\
\text { sticks. Bark used to } \\
\text { make rope. Produces } \\
\text { edible fruits. }\end{array}$ \\
\hline Salvadora persica & Adayto & $\begin{array}{l}\text { Firewood, medicinal, } \\
\text { forage, other } \\
\text { (toothbrush). }\end{array}$ & $\begin{array}{l}\text { Has antibacterial and } \\
\text { antiseptic compounds } \\
\text { used for overall oral } \\
\text { health and to treat oral } \\
\text { ailments. Provides } \\
\text { forage for livestock } \\
\text { (especially camels and } \\
\text { goats) and wildlife. }\end{array}$ \\
\hline $\begin{array}{l}\text { Cadaba } \\
\text { rotundifolia }\end{array}$ & Adengeli & $\begin{array}{l}\text { Firewood, medicinal, } \\
\text { veterinary, forage, other } \\
\text { (milk storage). }\end{array}$ & $\begin{array}{l}\text { Leaves crushed and } \\
\text { snorted or chewed to } \\
\text { alleviate cold symptoms, } \\
\text { asthma or headaches. } \\
\text { Ingested to combat any } \\
\text { gastrointestinal issues. } \\
\text { Leaves chewed and the } \\
\text { paste applied to open } \\
\text { wounds of people and } \\
\text { livestock to assist the } \\
\text { healing process. Critical } \\
\text { source of drought forage } \\
\text { (especially camels). } \\
\text { Branches burned and } \\
\text { smoke used to fumigate } \\
\text { milk containers. }\end{array}$ \\
\hline
\end{tabular}


Appendix 5. Maxent Jackknife validation assessment model output, including area under the receiver-operating curve (AUC) and percent contribution of model predictor variables for each model.

\begin{tabular}{|c|c|c|}
\hline Model Run & AUC & Variable Contribution \\
\hline Model 1 & 0.644 & $\begin{array}{l}\text { Distance to water }(78 \%) \text {, Distance to roads }(10 \%) \text {, August NDVI }(9 \%) \text {, } \\
\text { Slope }(2 \%) \text {, Elevation }(1 \%) \text {, Distance to settlements, }(0 \%) \text {, CTI }(0 \%) \text {. }\end{array}$ \\
\hline Model 2 & 0.998 & $\begin{array}{l}\text { Distance to water }(75 \%) \text {, August NDVI }(12 \%) \text {, Distance to roads }(10 \%) \text {, } \\
\text { Slope }(2 \%) \text {, Elevation }(1 \%) \text {, Distance to settlements, }(0 \%) \text {, CTI }(0 \%) \text {. }\end{array}$ \\
\hline Model 3 & 0.989 & $\begin{array}{l}\text { Distance to water }(73 \%) \text {, August NDVI }(12 \%) \text {, Distance to roads }(10 \%) \text {, } \\
\text { Slope }(3 \%) \text {, Elevation }(2 \%) \text {, Distance to settlements, }(0 \%) \text {, CTI }(0 \%) \text {. }\end{array}$ \\
\hline Model 4 & 0.792 & $\begin{array}{l}\text { Distance to water }(62 \%) \text {, August NDVI }(24 \%) \text {, Distance to roads }(8 \%) \text {, } \\
\text { Slope }(5 \%) \text {, Elevation }(1 \%) \text {, Distance to settlements, }(0 \%) \text {, CTI }(0 \%) \text {. }\end{array}$ \\
\hline Model 5 & 0.980 & $\begin{array}{l}\text { Distance to water }(73 \%) \text {, August NDVI }(11 \%) \text {, Distance to roads }(12 \%) \text {, } \\
\text { Slope }(3 \%) \text {, Elevation }(1 \%) \text {, Distance to settlements, }(0 \%) \text {, CTI }(0 \%) \text {. }\end{array}$ \\
\hline Model 6 & 0.931 & $\begin{array}{l}\text { Distance to water }(68 \%) \text {, August NDVI }(15 \%) \text {, Distance to roads }(11 \%) \text {, } \\
\text { Elevation }(3 \%) \text {, Slope }(3 \%) \text {, Distance to settlements, }(0 \%) \text {, CTI }(0 \%) \text {. }\end{array}$ \\
\hline Model 7 & 0.964 & $\begin{array}{l}\text { Distance to water }(71 \%) \text {, August NDVI }(18 \%) \text {, Distance to roads }(9 \%) \text {, } \\
\text { Slope }(2 \%) \text {, Elevation }(0 \%) \text {, Distance to settlements, }(0 \%) \text {, CTI }(0 \%) \text {. }\end{array}$ \\
\hline Model 8 & 0.262 & $\begin{array}{l}\text { Distance to water }(66 \%) \text {, Distance to roads (17\%), August NDVI }(14 \%) \text {, } \\
\text { Slope }(2 \%) \text {, CTI }(1 \%) \text {, Distance to settlements, }(0 \%) \text {, Elevation }(0 \%) \text {. }\end{array}$ \\
\hline Model 9 & 0.927 & $\begin{array}{l}\text { Distance to water }(69 \%) \text {, August NDVI }(13 \%) \text {, Distance to roads }(9 \%) \text {, } \\
\text { slope }(7 \%) \text {, Elevation }(2 \%) \text {, Distance to settlements, }(0 \%) \text {, CTI }(0 \%) \text {. }\end{array}$ \\
\hline Model 10 & 0.972 & $\begin{array}{l}\text { Distance to water }(72 \%) \text {, August NDVI }(12 \%) \text {, Distance to roads }(9 \%) \text {, } \\
\text { Slope }(4 \%) \text {, Elevation }(3 \%) \text {, Distance to settlements, }(0 \%) \text {, CTI }(0 \%) \text {. }\end{array}$ \\
\hline Model 11 & 0.458 & $\begin{array}{l}\text { Distance to water }(64 \%) \text {, August NDVI }(13 \%) \text {, Elevation }(12 \%) \text {, Distance } \\
\text { to roads }(8 \%) \text {, Slope }(3 \%) \text {, Distance to settlements, }(0 \%) \text {, CTI }(0 \%) \text {. }\end{array}$ \\
\hline Model 12 & 0.830 & $\begin{array}{l}\text { Distance to water (76\%), Distance to roads (10\%), August NDVI (10\%), } \\
\text { Slope (3\%), Elevation (1\%), Distance to settlements, }(0 \%) \text {, CTI }(0 \%) \text {. }\end{array}$ \\
\hline Model 13 & 0.883 & $\begin{array}{l}\text { Distance to water (65\%), August NDVI }(24 \%) \text {, Distance to roads }(8 \%) \text {, } \\
\text { Slope }(3 \%) \text {, Elevation }(0 \%) \text {, Distance to settlements, }(0 \%) \text {, CTI }(0 \%) \text {. }\end{array}$ \\
\hline Model 14 & 0.529 & $\begin{array}{l}\text { Distance to water }(68 \%) \text {, August NDVI }(20 \%) \text {, Distance to roads }(8 \%) \text {, } \\
\text { Slope }(2 \%) \text {, Elevation }(2 \%) \text {, Distance to settlements, }(0 \%) \text {, CTI }(0 \%) \text {. }\end{array}$ \\
\hline Model 15 & 0.891 & $\begin{array}{l}\text { Distance to water }(68 \%) \text {, August NDVI }(13 \%) \text {, Distance to roads }(9 \%) \text {, } \\
\text { Slope }(7 \%) \text {, Elevation }(3 \%) \text {, Distance to settlements, }(0 \%) \text {, CTI }(0 \%) \text {. }\end{array}$ \\
\hline Model 16 & 0.846 & $\begin{array}{l}\text { Distance to water }(65 \%) \text {, August NDVI }(20 \%) \text {, Distance to roads }(10 \%) \text {, } \\
\text { Slope }(3 \%) \text {, Elevation }(2 \%) \text {, Distance to settlements, }(0 \%) \text {, CTI }(0 \%) \text {. }\end{array}$ \\
\hline Model 17 & 0.967 & $\begin{array}{l}\text { Distance to water }(71 \%) \text {, August NDVI }(17 \%) \text {, Distance to roads }(9 \%) \text {, } \\
\text { Slope }(2 \%) \text {, Elevation }(1 \%) \text {, Distance to settlements, }(0 \%) \text {, CTI }(0 \%) \text {. }\end{array}$ \\
\hline Model 18 & 0.479 & $\begin{array}{l}\text { Distance to water (69\%), August NDVI }(21 \%) \text {, Distance to roads }(7 \%) \text {, } \\
\text { Slope }(2 \%) \text {, Elevation }(1 \%) \text {, Distance to settlements, }(0 \%) \text {, CTI }(0 \%) \text {. }\end{array}$ \\
\hline
\end{tabular}

